\title{
Article \\ Optimal Estimation of Proton Exchange Membrane Fuel Cells Parameter Based on Coyote Optimization Algorithm
}

\author{
Amlak Abaza ${ }^{1}$, Ragab A. El-Sehiemy ${ }^{1}\left(\mathbb{D}\right.$, Karar Mahmoud $^{2,3}{ }^{(D)}$, Matti Lehtonen ${ }^{2}(\mathbb{D}$ and \\ Mohamed M. F. Darwish 2,4,*(D)
}

1 Department of Electrical Engineering, Faculty of Engineering, Kafrelsheikh University, Kafrelsheikh 33516, Egypt; amlak.elhariri@eng.kfs.edu.eg (A.A.); elsehiemy@eng.kfs.edu.eg (R.A.E.-S.)

2 Department of Electrical Engineering and Automation, Aalto University, FI-00076 Espoo, Finland; karar.mostafa@aalto.fi or karar.alnagar@aswu.edu.eg (K.M.); matti.lehtonen@aalto.fi (M.L.)

3 Department of Electrical Engineering, Faculty of Engineering, Aswan University, Aswan 81542, Egypt

4 Department of Electrical Engineering, Shoubra Faculty of Engineering, Benha University, Cairo 11629, Egypt

* Correspondence: mohamed.m.darwish@aalto.fi or mohamed.darwish@feng.bu.edu.eg

check for

updates

Citation: Abaza, A.; El-Sehiemy, R.A.; Mahmoud, K.; Lehtonen, M.; Darwish, M.M.F. Optimal Estimation of Proton Exchange Membrane Fuel Cells Parameter Based on Coyote Optimization Algorithm. Appl. Sci. 2021, 11, 2052. https://doi.org/ 10.3390/app11052052

Academic Editor: Francisco Jesus Fernandez-Morales

Received: 30 January 2021

Accepted: 22 February 2021

Published: 25 February 2021

Publisher's Note: MDPI stays neutral with regard to jurisdictional claims in published maps and institutional affiliations.

Copyright: (c) 2021 by the authors. Licensee MDPI, Basel, Switzerland. This article is an open access article distributed under the terms and conditions of the Creative Commons Attribution (CC BY) license (https:/ / creativecommons.org/licenses/by/ $4.0 /)$.

\begin{abstract}
In recent years, the penetration of fuel cells in distribution systems is significantly increased worldwide. The fuel cell is considered an electrochemical energy conversion component. It has the ability to convert chemical to electrical energies as well as heat. The proton exchange membrane (PEM) fuel cell uses hydrogen and oxygen as fuel. It is a low-temperature type that uses a noble metal catalyst, such as platinum, at reaction sites. The optimal modeling of PEM fuel cells improves the cell performance in different applications of the smart microgrid. Extracting the optimal parameters of the model can be achieved using an efficient optimization technique. In this line, this paper proposes a novel swarm-based algorithm called coyote optimization algorithm (COA) for finding the optimal parameter of PEM fuel cell as well as PEM stack. The sum of square deviation between measured voltages and the optimal estimated voltages obtained from the COA algorithm is minimized. Two practical PEM fuel cells including $250 \mathrm{~W}$ stack and Ned Stack PS6 are modeled to validate the capability of the proposed algorithm under different operating conditions. The effectiveness of the proposed COA is demonstrated through the comparison with four optimizers considering the same conditions. The final estimated results and statistical analysis show a significant accuracy of the proposed method. These results emphasize the ability of COA to estimate the parameters of the PEM fuel cell model more precisely.
\end{abstract}

Keywords: fuel cell; proton exchange membrane; parameter estimation; coyote optimization algorithm

\section{Introduction}

No doubt, clean energy technologies play a part an important role in defeating fossil fuel tiredness and global pollution. Proton exchange membrane fuel cells (PEMFCs) are prime examples of these technologies for electrochemical energy conversion [1]. Proton exchange membrane fuel cells (PEMFCs) are considered an effective variant to diesel distributed generations that can back up electricity and balance grid power. The key merits of these PEMFCs in power system applications are high start-up reliability, little costs for startup, low carbon emissions, rapid reaction to demand changes, and quiet operation [1-5]. For these reasons, the hydrogen-fueled cars on the global market have been fed by PEMFCs, where they participate in about $90 \%$ of fuel cell research and development [6]. For instance, in Finland, a substantial amount of hydrogen is extracted as a byproduct in industrial factories that specialize in chlorine and sodium chlorate, whereas the hydrogen quality is adequate for employment as a sustainable fuel in PEMFCs [7,8]. As a result, this hydrogen can be used in PEMFC power plants that operate at partial loading conditions, and so they can yield an important quick load cover in power systems, besides other renewable energy sources [9-12]. In this regard, fuel cell units are considered as electrochemical 
energy conversion devices in AC and DC power networks [13,14]. These units can convert chemical energy to electrical energy besides heat while they use oxygen and hydrogen as fuel. It is a low-temperature form that uses a noble metal catalyst, such as platinum, at reaction sites. In addition, energy releases during the reaction [15-17]. The fuel cell chemical reactions produce dc electricity, heat, and liquid water [18,19].

The parameter estimation of fuel cells has attracted research interest in recent years. A PEMFC is considered one of the most promising devices that convert chemical energy fuels into electrical energy based on electrochemical responses [15-18]. Specifically, the PEMFCs have numerous rewards, e.g., good electrical efficiency, little emission, and flexibility in fuel, that make them applicable to diverse applications [20-24]. For instance, they can apply in the combined tough issue owing to PEMFC being a compound multivariable powerfully coupled scheme. For getting precise values for these parameters, numerous methods have been introduced in the literature. Most importantly, the usage of meta-heuristics has arisen as a viable and talented choice by reason of their robustness, ease of application, simplicity, and derivative-free generation of both electric power as well as heat.

To additionally enhance the PEMFC performance, numerous efforts have been made by researchers that are carried out to guess the parameters of the PEMFC, which can be summarized as follows:

- $\quad$ Ref. [16] applies particle swarm optimization (PSO) method for PEMFC parameter extraction;

- $\quad$ Ref. [25] used hybrid adaptive differential evolution procedure for the extraction process of PEMFC parameters;

- Ref. [26] develops grasshopper optimization algorithm for PEMFC parameter extraction;

- $\quad$ Ref. [27] proposed multi-verse optimizer for parameter PEMFC extraction.

- The hybrid artificial bee colony technique for estimating the parameter of PEMFC in [28];

- The estimation of PEMFC parameters was obtained by a combination between backtracking search technique combined with Burger's chaotic map in [29];

- A P systems-based optimizer for parameter estimation of PEMFC model in [30];

- Another optimization called biogeography-based optimization technique improved by adding with mutations to estimate the parameter of two renewable energy cells solar and fuel cells in [31];

- $\quad$ The parameter estimation problem based on the fuel cell polarization curve using bird mating optimization algorithm in [32];

- $\quad$ Refs. [18,33,34] proposed a hybrid genetic algorithm for estimation the PEMFC parameters;

- In [35], the harmony search optimizer was developed for parameter identification of a PEMFC model;

- Due to the recent development in machine learning methods [36,37], the authors of [38] the convolutional neural network have been used for the PEMFC parameters identification;

- In [39], the PEMFC parameters are extracted based on the polarization curve and provide the behavior analysis considering the various temperature impacts;

- In [5], the Matlab/Simulink-based model was proposed in conjunction with a waste heat recovery system; and

- In [40], the parameters of PEMFC are identified by using a new modified version of the differential algorithm associated with the collective guidance factor.

In recent years, many optimization techniques were developed for several engineering problems. In particular, COA is a recent method for global optimization problems. It is a population-based metaheuristic technique. The COA has been classified as both swarm intelligence and evolutionary heuristic and it is based on the coyotes' behavior. The fitness function is reduced using the social structure and exchanging experiences between the coyotes instead of hunting only. In this regard, we propose a novel method to detect 
the unidentified parameter of the electrochemical model for PEM fuel cells in this paper. Specifically, a new swarm-based algorithm called coyote COA is developed to determine the accurate parameter of PEM fuel cells. In the proposed optimization model, the fitness function is minimized based on both the social structure and swapping experiences amongst the coyotes instead of only hunting. The main merit of COA is that it has no control parameters, and therefore it is a promising optimization tool compared with those in the literature. The efficacy of the proposed method is established while a significant improvement in the accuracy of the estimated parameters of PEM fuel cells is attained.

The reminder of this work is organized as follows: In Section 2, the electrochemical models of the fuel cell are presented. Section 3 presents the solution methodology of parameter estimation by using COA. Section 4 demonstrates the results and discussion of the proposed COA capability for solving the parameter estimation problem with aid of PEM fuel cells. Finally, Section 5 concludes the remarks and outputs of this research work.

\section{Electrochemical Model of PEM Fuel Cell}

\subsection{Operating Principles of PEM Fuel Cell}

The PEM fuel cell consists of three basic elements, anode, proton exchange membrane, and cathode. The hydrogen gas ionizes producing protons and electrons. The reaction of the anode site is given as follows:

$$
\text { Anode (oxidation) : } 2 \mathrm{H}_{2} \rightleftarrows 4 H^{+}+4 e^{-} \text {. }
$$

At the cathode site, a reduction process occurs, where oxygen molecules react with electrons from the circuit and protons from the electrolyte (proton exchange membrane) forming water. Equations (2) and (3) describe the reaction at the cathode site and the overall reaction of the cell.

$$
\begin{gathered}
\text { Cathode (reduction) : } 4 \mathrm{H}^{+}+4 e^{-}+\mathrm{O}_{2} \rightleftarrows 2 \mathrm{H}_{2} \mathrm{O} \\
\text { Overall reaction }: 2 \mathrm{H}_{2}+\mathrm{O}_{2} \rightleftarrows 2 \mathrm{H}_{2} \mathrm{O} .
\end{gathered}
$$

\subsection{Output Voltage of PEM Fuel Cell}

The output voltage at the terminals of a single PEM fuel cell, $V_{\text {cell }}$, has resulted from thermodynamic potential, $E_{\text {Nernst }}$, and the potential losses within the conversion process $[16,41]$,

$$
V_{\text {cell }}=E_{\text {Nernst }}-(\text { All losses in a fuel cell }) .
$$

The thermodynamic potential $E_{\text {Nernst }}$ can be determined from Equation (5) for the fuel cell. It depends on hydrogen/oxygen at real functioning conditions, the partial pressure of hydrogen $\left(P_{\mathrm{H}_{2}}^{*}\right)$ and oxygen $\left(P_{\mathrm{O}_{2}}^{*}\right)$, and temperature (T in Kelvin).

$$
\begin{gathered}
E_{\text {Nernst }}=1.229-\left(8.5 \times 10^{-3}\right)(T-298.15)+\left(4.308 \times 10^{-5}\right) T \ln \left(P_{H_{2}}^{*} \times \sqrt{P_{\mathrm{O}_{2}}^{*}}\right) \\
P_{\mathrm{H}_{2}}^{*}=\frac{R H_{a} \cdot P_{\mathrm{H}_{2} \mathrm{O}}}{2}\left[\left(1 / \frac{R H_{a} \cdot P_{\mathrm{H}_{2} \mathrm{O}}}{P_{a}} e^{\left(1.635\left(\frac{I}{A}\right) / T^{1.334}\right)}\right)-1\right] \\
P_{\mathrm{O}_{2}}^{*}=R H_{c} \cdot P_{\mathrm{H}_{2} \mathrm{O}}\left[\left(1 / \frac{R H_{c} \cdot P_{\mathrm{H}_{2} \mathrm{O}}}{P_{c}} e^{\left(4.192\left(\frac{I}{A}\right) / T^{1.334}\right)}\right)-1\right]
\end{gathered}
$$

where, $P_{\mathrm{H}_{2} \mathrm{O}}$ is the saturation pressure of water vapor in atm, given in Equation (8). $R H_{a}$ and $R H_{c}$ are relative humidity of vapor at anode and cathode respectively [41].

$$
\log _{10}\left(\mathrm{P}_{\mathrm{H}_{2} \mathrm{O}}\right)=2.95 \times 10^{-2}(\mathrm{~T}-273.15)-9.18 \times 10^{-5}(\mathrm{~T}-273.15)^{2}+1.44 \times 10^{-7}(\mathrm{~T}-273.15)^{3}-2.18
$$

The losses associated with PEM fuel cells are classified into three categories; activation, ohmic, and concentration losses. These losses caused the variation of the output voltage of 
the fuel cell with the load current [18]. The relation between cell terminal voltage and the load current is known as the polarization curve.

Figure 1 depicts the voltage losses of PEM fuel cells at different current levels. The PEM fuel cell has three categories of losses; activation loss, ohmic voltage loss, and concentration loss.

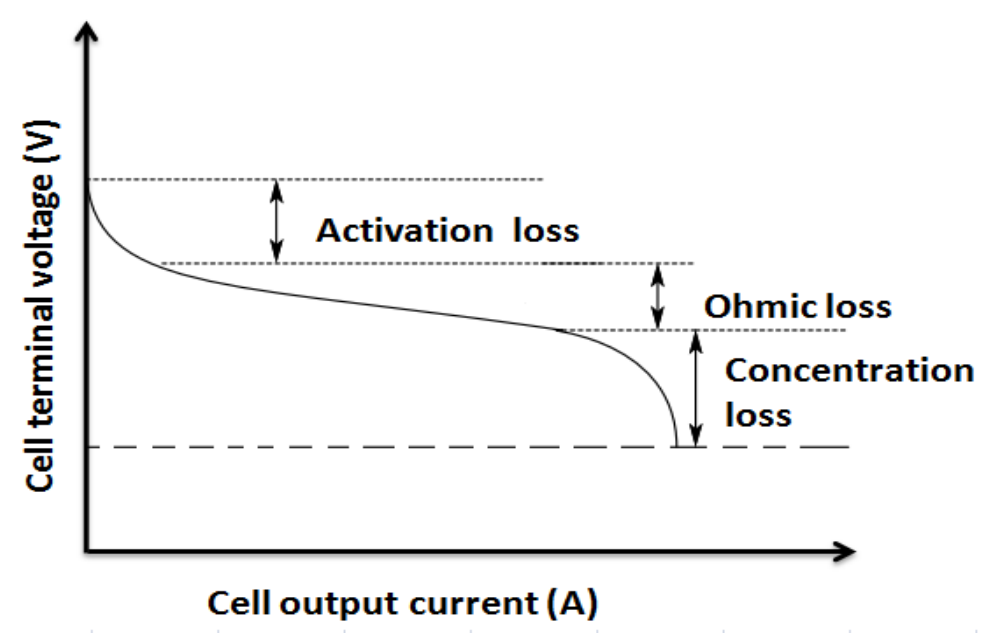

Figure 1. Polarization curve of proton exchange membrane (PEM) fuel cell.

Activation cell loss is the first category and the most dominant loss, especially at the beginning of the reaction. This is because of the slowness of the reaction resulting from electronic barriers that needed to be overcome [17]. This loss is defined as the portion of voltage, lost to enable ions to flow from one electrode to another [26-28]. It can be determined by Equation (9).

$$
V_{\text {activation }}=-\left[\xi_{1}+\xi_{2} T+\xi_{3} T\left(\ln \left(C_{O_{2}}^{*}\right)\right)+\xi_{4} T(\ln (I))\right]
$$

where the factors $\xi_{1}-\xi_{4}$ are coefficients for activation loss voltage varied due to load current, $I$, at actual temperature, $T(\mathrm{~K})$, and oxygen concentration, $C_{\mathrm{O}_{2}}^{*}$.

The value of $C_{\mathrm{O}_{2}}^{*}$ depends on the partial pressure of oxygen $P_{\mathrm{O}_{2}}^{*}$ and the actual temperature.

$$
\mathrm{C}_{\mathrm{O}_{2}=}^{*}\left[P_{\mathrm{O}_{2}}^{*} /\left(5.08 \times 10^{6}\right)\right] e^{(498.15 / T)}
$$

The second category of losses is the ohmic voltage loss. It has resulted from resistance to electron transfer through cell electrodes and the resistance to proton flow in the solid polymer membrane.

$$
V_{\text {ohmic }}=V_{\text {ohmic }}^{\text {electronic }}+V_{\text {ohmic }}^{\text {proton }}=I R_{c}+I R_{m}
$$

where the value of electronic resistance, $R_{c}$, is unknown. It is considered approximately constant over the cell operating conditions. The value of proton membrane resistance, $R_{m}$, depends on the membrane characteristics; specific resistivity, $\rho_{m}(\mathrm{ohm} . \mathrm{cm})$, area $A\left(\mathrm{~cm}^{2}\right)$, and thickness $l(\mathrm{~cm})$. For Nafion membrane, the thickness considered maybe [115:5 mil $(127 \mu \mathrm{m})][26,27,41]$.

$$
R_{m}=\rho_{m} l / A
$$

The value of $\rho_{m}$ can be determined using an empirical expression as follows [41]:

$$
\rho_{m}=\frac{181.6\left[1+0.03\left(\frac{I}{A}\right)+0.062\left(\frac{T}{303}\right)^{2} \cdot\left(\frac{I}{A}\right)^{2.5}\right.}{\left[\lambda-0.634-3\left(\frac{I}{A}\right) e^{(4.18[T-303] / T)}\right]} .
$$


The adjustable variable $\lambda$, reflects the effective water content of the membrane. It may be 14 under ideal, 100\% relative humidity conditions to 22 and 23 under supersaturated conditions [41].

The third voltage loss of PEM fuel cell is the concentration loss, $V_{\text {concentraion. }}$ It takes place at a high limiting current $\left(I_{\max }\right)$ where the reduction of concentration is a result of the difficulty in transporting sufficient reactant to electrode surface [26-28].

$$
V_{\text {concentraion }}=-b \times \ln \left(\left(J_{\max }-J\right) / J_{\max }\right)
$$

where $b$ is the unknown parametric coefficient.

The output voltage of the PEM fuel cell is determined by Equation (15). If fuel cells, $n_{\text {cells }}$, are connected in series to obtain the desired voltage, the resulted stack voltage will be the summation of the output of all cells, as follows [19,27]:

$$
\begin{gathered}
V_{\text {cell }}=E_{\text {Nernst }}-\left(V_{\text {activation }}+V_{\text {ohmic }}+V_{\text {concentraion }}\right) \\
V_{\text {stack }}=n_{\text {cell }} \times V_{\text {cells }} .
\end{gathered}
$$

\section{Determination of PEMFC Parameter by COA}

\subsection{Coyote Optimization Algorithm (COA)}

Figure 2 shows the flow chart of COA that is developed for solving the parameter estimation problem of the PEM fuel cell. The total population of coyotes is divided into a number of packs, $N_{P} \in N^{*}$ packs. Each pack contains $N_{C} \in N^{*}$ coyotes. The number of the coyote in each pack is considered as a static value. The total number population can be obtained by multiplying both $N_{P}$ and $N_{C}$. The solution to the optimization problem depends on the social conditions of the coyote. Each coyote can represent a possible solution to the problem based on its social conditions, soc. The social conditions of the coyote characterize the control variables $(\bar{X})$ of a stated global optimization model [42].

$\mathrm{COA}$ is a d-dimensional environment representing the space of decision variables. The social condition $s o c$, of $c$ th coyote that belongs to the Pth pack at $t$ th instant of time, is $\operatorname{soc}_{C}^{P, t}$. It can be written as:

$$
\operatorname{soc}_{C}^{P, t}=\bar{X}=\left(x_{1}, x_{2}, x_{31}, \ldots ., x_{d}\right)
$$

The evaluation of coyote's social conditions determines the objective function, $f_{i t}^{P, t}$, which reveals the adaptation of coyotes to environmental conditions.

COA is achieved starting from the initialization of the global population of coyotes, packs with $N_{C}$ coyotes. The preliminary social conditions are designated arbitrarily for each coyote $c$ th of $P$ th at instantaneous $t$ th and $j$ th dimension as follows:

$$
\operatorname{soc}_{C, j}^{P, t}=L B_{j}+r_{j} \times\left(U B_{j}-L B_{j}\right)
$$

where, $L B_{j}$ and $U B_{j}$ represent the lower and upper bounds of the decision variable $j$ th of the search space, $d$. The value of the real random number $r_{j}$ lies in the range $[0,1]$, which is generated using uniform probability.

The evaluation of the coyotes' adaptive corresponding to the current decision variables is determined.

$$
f i t_{C}^{P, t}=f\left(\operatorname{soc}_{C}^{P, t}\right)
$$

The diversity of coyotes occurs due to leaving a pack and joining another one. The probability of a coyote leaving its pack or evicted from a pack is $P_{e}$. It depends on $N_{C}$ and given as follows:

$$
P_{e}=0.005 N_{C}^{2} \text {. }
$$

The number of $N_{C}$ that makes $P_{e}>1$ is limited to 14 coyotes inside the pack. 


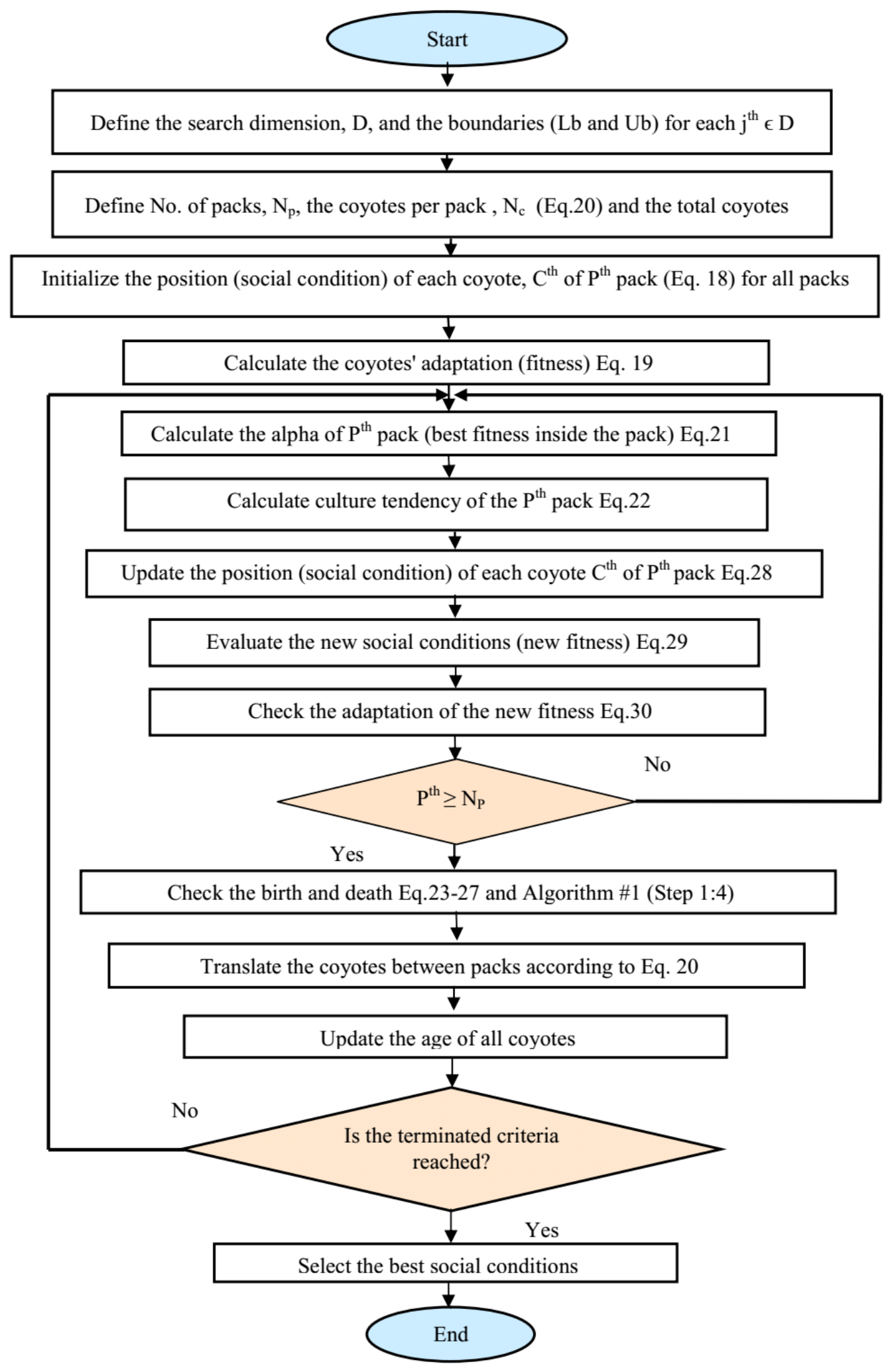

Figure 2. Flow chart of the proposed coyote optimization algorithm (COA).

The best social adapted to the environment, alpha, is only one for the global population. It represents the best solution to the optimization problem at $t$ th instant of time of Pth pack.

$$
\operatorname{alpha} a^{P, t}=\left\{\operatorname{soc}_{C}^{P, t} \mid \arg _{C}=\left\{1,2, \ldots, N_{C}\right\} \operatorname{minf}\left(\operatorname{soc}_{C}^{P, t}\right)\right\}
$$


The COA as swarm intelligence facilitates the distribution of social situations and relations all info from the total population. COA, formerly, calculates the cultural tendency of the pack,

$$
\text { cult }_{j}^{P, t}=\left\{\begin{array}{c}
O_{\frac{\left(N_{C}+1\right)}{2}, j}^{P}, N_{C} \text { is odd } \\
\frac{O_{\frac{N_{C}}{2}, t}^{P, t}+O_{\left(N_{C}+1\right)}^{P, t}, j}{2} \text { otherwise }
\end{array}\right.
$$

where $O^{P, t}$ represents the ranked decision variables (i.e., social conditions) of all coyotes in the $p$ th pack at $t$ th instant for every $j$ in the search space of control variables $d$. The cultural tendency of the pack represents the median social conditions of all coyotes from that defined pack.

The birth of a coyote, as well as the death, affects the size of the population. For the purpose of retaining the pack size static, the developed COA tool calculates the ages of all coyotes within a pack as $a g e_{C}^{P, t} \in N$. Further, the birth of an updated coyote is denoted by a mixture of the social circumstances of two parents in a pack, that is selected arbitrarily, as follows:

$$
\operatorname{Pup}_{j}^{P, t}=\left\{\begin{array}{c}
\operatorname{soc}_{r 1, j}^{P, t}, \text { rand }<P_{s} \text { or } j=j_{1} \\
\operatorname{soc}_{r, 2, j}^{P, t}, \text { rand } j \geq\left(P_{s}+P_{a}\right) \text { or } j=j_{2} \\
R_{j}, \text { Otherwise }
\end{array}\right.
$$

where $r_{1}$ and $r_{2}$ represent the two random parameters of coyotes within the Pth pack. $j_{1}$ and $j_{2}$ are arbitrary dimensions of the optimization model. $P_{s}$ and $P_{a}$ represent, respectively, the scatter and association probabilities, specified by Equations (24) and (25). $R_{j}$ represents an arbitrary number that lies in the control variable bound of the $j$ th dimension. Note that the values of the real random number $r$ and $j$ lie in the array [0.1], where they are produced by uniform probability.

$$
\begin{gathered}
P_{s}=1 / d \\
P_{a}=\left(1-P_{s}\right) / 2
\end{gathered}
$$

Top reserve the population size as a static one, the birth and the death of specified coyote are treated by the following stages (Algorithm 1):

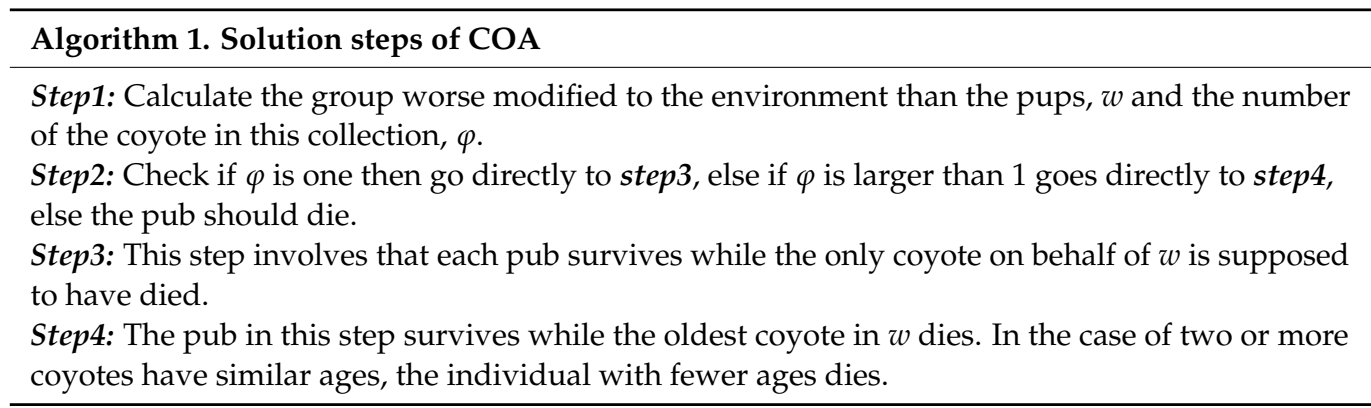

The interaction between all coyotes in the global population in general and that inside each pack especially aid the cultural exchanging. The intelligence of coyotes and the sufficient organization assistance them to appraise their social circumstances considering the finest one inside the pack, alpha $a^{P, t}$, and the cultural tendency of the pack, $c u l t^{P, t}$. This can be achieved by taking two factors $\delta_{1}$ and $\delta_{2}$ into account when a coyote updates its social conditions. The influence $\delta_{1}$ is occupied as the change from an arbitrary coyote $(\mathrm{Cr} 1)$ within the pack to the alpha coyote in a similar pack. Further, the pack influence $\left(\delta_{2}\right)$ is the change from an arbitrary coyote $(\mathrm{Cr} 2)$ of a pack to the cultural tendency of the same pack.

$$
\begin{gathered}
\delta_{1}=\operatorname{alpha^{P,t}}-\operatorname{soc}_{C r 1}^{P, t} \\
\delta_{2}=\operatorname{cult}^{P, t}-\operatorname{soc}_{C r 2}^{P, t}
\end{gathered}
$$


The new social condition of a coyote is updated as follows:

$$
n e w \_\operatorname{soc}_{C}^{P, t}=\operatorname{soc}_{C}^{P, t}+r_{1} \delta_{1}+r_{2} \delta_{2}
$$

where, $r_{1}$ and $r_{2}$ are random numbers within the range $[0,1]$, which generated using uniform probability.

The evaluation of the new social condition results in a new value of the objective function.

$$
n e w \_f i t_{C}^{P, t}=f\left(n e w \_s o c_{C}^{P, t}\right)
$$

At the next $(t+1)$ th instant of time, the coyotes decide if the new social condition is better than the older or not. If $n e w_{-} f i t_{C}^{P, t}$ is less than $f i t_{C}^{P, t}$ (for minimization problem), then the decision is that the new social conditions are the best at that instant. Equation (30) explains this decision.

$$
\operatorname{soc}_{C}^{P, t+1}=\left\{\begin{array}{c}
\text { new_soc } c_{C}^{P, t}, \text { new_fit } t_{C}^{P, t}<\text { fit }_{C}^{P, t} \\
\operatorname{soc}_{C}^{P, t} \text { otherwise }
\end{array}\right.
$$

The global solution to the problem is that the social conditions of a coyote that best adapted itself to the environment.

\subsection{Parameter Optimization of PEM Fuel Cell}

The optimization of the proposed problem aims to identify the unknown parameter of the electrochemical model for PEMFCs. The optimized model must be accurate as possible to converge with the actual model. The set of control variables $(x)$ of the parameter estimation problem is represented by $x=\left\{\xi_{1}, \xi_{2}, \xi_{3}, \xi_{4}, R_{c}, \lambda\right.$, and $\left.b\right\}$. It is important to optimize these seven parameters affecting Equations (9)-(14) to obtain the stack output voltage of the modelled PEMFCs. The calculated stack voltage is required to converge with the experimental values of the actual stack. To realize the convergence, the sum of square error (SSE) between the measured and modelled stack voltage must be minimized. The Coyote optimization algorithm as a metaheuristic optimization algorithm is used to minimize the objective function of the problem.

$$
S S E=\sum_{k=1}^{n}\left[V_{\text {measured }}(k)-V_{\text {stack }}(k)\right]^{2}
$$

where $n$ represents the number of real voltages at dissimilar load current. The problem can be stated as an optimization problem, as follows:

$$
O F=\min (\operatorname{SSE}(x))
$$

subject to

$$
\begin{gathered}
\xi_{\mathrm{i}}^{\text {min }} \leq \xi_{\mathrm{i}} \leq \xi_{\mathrm{i}}^{\max } \text { for } i=1,2,3 \text { and } 4 \\
\mathrm{R}_{\mathrm{c}}^{\text {min }} \leq \mathrm{R}_{\mathrm{c}} \leq \mathrm{R}_{\mathrm{c}}^{\max } \\
\lambda^{\text {min }} \leq \lambda \leq \lambda^{\text {max }} \\
b^{\text {min }} \leq b \leq b^{\text {max }}
\end{gathered}
$$

All control variables are preserved within the lower and upper boundaries as presented in Equation (33).

\section{Results and Discussion}

To validate the efficiency of the proposed COA, two practical cases of $250 \mathrm{~W}$ PEM stack [26,27] and NedStack PS6 [43-45] have been studied. The proposed algorithm is verified by means of the data in the literature $[26,27,44]$. The parameters, technical, and working circumstances of the tested stacks are given in Table 1. Further, Table 2 shows the lower and upper bounds of the decision variables of the model at two different operating condi- 
tions, (operating condition \#1: 1/1 bar and $343.15 \mathrm{~K}$ ) for both stacks ( $250 \mathrm{~W}$ and NedStack PS6) and (operating condition \#2: $3 / 5$ bar and $353.15 \mathrm{k}$ ) for $250 \mathrm{~W}$ stack. The simulation results have been compared to other literature works [18-22]. Moreover, four competitive methods; SSA [46], SCA [47], MFO [48], and PSO [16] have been implemented to test the effectiveness of COA. For a fair comparison, all of populations are set to 100 with 400 iterations. All simulation results were carried out using the MATLAB R2016b software on a PC with Intel (R) Core (TM) i3- CPU M370@2.4 GHz 3 GB (RAM).

Table 1. Technical data and operating conditions of PEM fuel cell stack.

\begin{tabular}{ccc}
\hline 250 W Stack & \multicolumn{1}{c}{ NedStack PS6 } \\
\hline & Technical data & \\
\hline Stack Parameter & Value & Value \\
Number of cells in a stack, $\mathrm{n}_{\text {cells }}$ & 24 & 65 \\
Active cell Area $\left(\mathrm{cm}^{2}\right)$ & 27 & 240 \\
Nafion membrane thickness 1 & $127 \mu \mathrm{m}$ & $178 \mu \mathrm{m}$ \\
Maximum current density Jmax $\left(\mathrm{A} \mathrm{cm}{ }^{-2}\right)$ & 0.86 & 1.2 \\
Rated power $(\mathrm{W})$ & 250 & 6000 \\
\hline & Operating conditions & \\
\hline$P_{a}$ (bar) & $1-3$ & $1-3$ \\
$P_{c}$ (bar) & $1-5$ & $343.15-353.15$ \\
Stack temperature $T(\mathrm{~K})$ & $343.15-353.15$ & 1 \\
Relative humidity in anode $R H_{a}$ & 1 & 1 \\
Relative humidity in cathode $\mathrm{RH}_{c}$ & 1 & $60-32$ \\
Voltage $(\mathrm{V})$ & 15.09 & 225 \\
Maximum Current $(\mathrm{A})$ & 22.1 & $\mathrm{H}_{2}$ and Air \\
Reactants & $\mathrm{H}_{2}$ and Air &
\end{tabular}

Table 2. Lower and upper bounds of PEM stack decision variables of two studied cases.

\begin{tabular}{ccccccc}
\hline FC & \multicolumn{3}{c}{ 250 W FC } & \multicolumn{2}{c}{ NedStack PS6 } \\
\hline \multirow{2}{*}{ Parameter } & \multicolumn{2}{c}{ Bound \#1 } & \multicolumn{2}{c}{ Bound \#2 } & \multicolumn{2}{c}{ 343.15 K, 1/1 Bar } \\
\cline { 2 - 7 } & Lower & Upper & Lower & Upper & Lower & Upper \\
\hline$\xi_{1}$ & -0.952 & -0.944 & -1.1996 & -0.8532 & -1.1997 & -0.8532 \\
$\xi_{2}$ & 0.001 & 0.005 & 0.001 & 0.005 & 0.001 & 0.005 \\
$\xi_{3}$ & $7.4 \times 10^{-5}$ & $7.8 \times 10^{-5}$ & $3.6 \times 10^{-5}$ & $9.8 \times 10^{-5}$ & $3.6 \times 10^{-5}$ & $9.86 \times 10^{-5}$ \\
$\xi_{4}$ & $-1.98 \times 10^{-4}$ & $-1.88 \times 10^{-5}$ & $-2.6 \times 10^{-4}$ & $-9.54 \times 10^{-5}$ & $-26 \times 10^{-5}$ & $-9.54 \times 10^{-5}$ \\
$\lambda$ & 14 & 23 & 10 & 24 & 13 & 23 \\
$R_{c}$ & 0.0001 & 0.0008 & 0.0001 & 0.0008 & 0.0001 & 0.0008 \\
$b$ & 0.016 & 0.5 & 0.0136 & 0.5 & 0.0136 & 0.05 \\
\hline
\end{tabular}

Herein, the optimization techniques aim to minimize the square deviation between measured V-I data and the estimated data by the stack model. This optimization process results in extracting the optimal values of the decision variables $\left(\xi_{1}, \xi_{2}, \xi_{3}, \xi_{4}, R_{c}, \lambda\right.$ and $\left.b\right)$ of the PEM stack model. These variables are used to obtain an accurate model of the PEM fuel cells stack. The simulation results for the two studied cases are explained as follows:

\subsection{Case 1: 250 W PEM Stack}

Table 3 clarifies the extracted optimal decision variables using the proposed algorithm, COA compared to existing literature, and other four competitive methods at $343.15 \mathrm{~K}$ and $1 / 1$ bar. In our problem, it is anticipated to lessen the variance between the output voltages of the proposed optimization model with respect to the measured values at dissimilar current values. As noticed from Table 3, the ranking of SSE is COA followed by PSO [16], HGA [18], HADE [25], MVO [27], SSA [46], SCA [47], and MFO [48]. 
Table 3. Optimal decision variables obtained with different method compared to COA for $250 \mathrm{~W}$ proton exchange membrane fuel cell (PEMFC) at operating conditions \#1.

\begin{tabular}{|c|c|c|c|c|c|c|c|c|}
\hline \multicolumn{9}{|c|}{ Operating Condition 1/1 Bar and $T=343.15$ and Boun\#1 of Decision Variables } \\
\hline $\begin{array}{l}\text { PEMFC } \\
\text { Parame- } \\
\text { ter }\end{array}$ & $\begin{array}{l}\text { HGA Hybrid } \\
\text { Genetic } \\
\text { Algorithm [18] }\end{array}$ & HADE [25] & MVO [27] & SSA [46] & SCA [47] & MFO [48] & $\begin{array}{c}\text { Particle } \\
\text { Swarm Opti- } \\
\text { mization } \\
\text { (PSO) [16] }\end{array}$ & $\begin{array}{l}\text { Proposed } \\
\text { COA }\end{array}$ \\
\hline $\begin{array}{l}\xi_{1} \\
\xi_{2}\end{array}$ & $\begin{array}{c}-0.94495 \\
3.018 \times 10^{-3}\end{array}$ & $\begin{array}{c}-0.944 \\
3.078 \times 10^{-3}\end{array}$ & $\begin{array}{c}-0.9447 \\
3.049 \times 10^{-3}\end{array}$ & $\begin{array}{l}-0.94915082 \\
2.93 \times 10^{-3}\end{array}$ & $\begin{array}{c}-0.944 \\
2.96 \times 10^{-3}\end{array}$ & $\begin{array}{c}-0.952 \\
2.98 \times 10^{-3}\end{array}$ & $\begin{array}{c}-0.944 \\
2.96 \times 10^{-3}\end{array}$ & $\begin{array}{l}-0.94400281 \\
2.90 \times 10^{-3}\end{array}$ \\
\hline$\xi_{3}$ & $7.4 \times 10^{-5}$ & $7.80 \times 10^{-5}$ & $\begin{array}{c}7.78236 \times \\
10^{-5}\end{array}$ & $7.49 \times 10^{-5}$ & $7.80 \times 10^{-5}$ & $7.80 \times 10^{-5}$ & $7.80 \times 10^{-5}$ & $7.40 \times 10^{-5}$ \\
\hline$\xi_{4}$ & $-1.88 \times 10^{-4}$ & $1.88 \times 10^{-4}$ & $\begin{array}{c}-1.644 \times \\
10^{-4}\end{array}$ & $\begin{array}{c}-1.39 \times \\
10^{-4}\end{array}$ & $\begin{array}{c}-1.36 \times \\
10^{-4}\end{array}$ & $\begin{array}{c}-1.42 \times \\
10^{-4}\end{array}$ & $\begin{array}{c}-1.42 \times \\
10^{-4}\end{array}$ & $\begin{array}{c}-1.42 \times \\
10^{-4}\end{array}$ \\
\hline$\lambda$ & 23 & 23 & 16.021 & 23 & 23 & 23 & 23 & 23 \\
\hline $\mathrm{R}_{\mathrm{c}}$ & $1.0 \times 10^{-4}$ & $1.0 \times 10^{-4}$ & $1.204 \times 10^{-4}$ & $3.62 \times 10^{-4}$ & $1.53 \times 10^{-4}$ & $1.00 \times 10^{-4}$ & $1.00 \times 10^{-4}$ & $1.00 \times 10^{-4}$ \\
\hline$b$ & 0.029145 & 0.03267 & 0.02369 & 0.01939 & 0.02217 & 0.02013 & 0.02013 & 0.02013 \\
\hline SSE & 16.608 & 15.6669 & 15.1316 & 0.318438868 & 0.347078342 & 0.292582747 & 0.292582749 & 0.292571646 \\
\hline
\end{tabular}

Hybrid genetic algorithm (HGA); hybrid adaptive differential evolution algorithm (HADE); Multi-verse optimizer (MVO); Sine Cosine Algorithm (SCA); moth-flame optimization (MFO); coyote optimization algorithm (COA).

At operating condition \#2 ( $353.15 \mathrm{~K}$ and $3 / 5$ bar), the comparison of the simulation results shows that COA has the ability to estimate an accurate model of PEM $250 \mathrm{w}$ stack with lower SSE (0.6691) compared to the others, Table 4. The value of SSE with COA is less than HABC by $91.64 \%$, HADE by $91.62 \%$, and $81.33 \%$ compared to MOV. Moreover, it is noticed from Figure $3 a$ that the convergence of the objective function occurred quickly smoothly after about 27 iterations. The polarization (I-V) curve is shown in Figure $3 \mathrm{~b}$ with the effect of different losses. The activation loss, as noticed, has a large value compared to the concentration loss which has been recorded as the lower value. Figure 4 shows the polarization curve (V-I curve) of the $250 \mathrm{~W}$ PEM fuel cell stack at different operating conditions and two boundaries of decision variables (bound \#1 and bound\#2). The figure shows the best agreement of the model curve with measured values. The power of the stack model is plotted and compared to the measured value, as presented in Figure 5.

Table 4. Optimal decision variables obtained with different method compared to COA for PEMFC at operating conditions \#2.

\begin{tabular}{ccccc}
\hline \multicolumn{4}{c}{ Operating Condition 3/5 Bar and T $=\mathbf{3 5 3 . 1 5}$ and Bound \#2 of Decision Variables } \\
\hline $\begin{array}{c}\text { PEMFC } \\
\text { Parameter }\end{array}$ & HABC [28] & HADE [25] & MVO [27] & Proposed COA \\
\hline$\xi_{1}$ & -0.8540 & -0.8532 & -0.918163 & -1.1449 \\
$\xi_{2}$ & $2.8498 \times 10^{-3}$ & $2.810093 \times 10^{-3}$ & $3.212993 \times 10^{-3}$ & $3.0118 \times 10^{-3}$ \\
$\xi_{3}$ & $8.3371 \times 10^{-5}$ & $8.092 \times 10^{-5}$ & $8.70306 \times 10^{-5}$ & $3.6000 \times 10^{-5}$ \\
$\xi_{4}$ & $-1.2940 \times 10^{-4}$ & $-1.287 \times 10^{-4}$ & $-1.80253 \times 10^{-4}$ & $-1.4470 \times 10^{-4}$ \\
$\lambda$ & 14.2873 & 14.0448 & 15.1921 & 24.0000 \\
$\mathrm{R}_{\mathrm{C}}$ & $1.0000 \times 10^{-4}$ & $1.0000 \times 10^{-4}$ & $4.22329 \times 10^{-4}$ & $1.0000 \times 10^{-4}$ \\
$b$ & $3.40 \times 10^{-2}$ & $3.35374 \times 10^{-2}$ & $1.80021 \times 10^{-2}$ & $2.0856 \times 10^{-2}$ \\
$\mathrm{SSE}$ & 8.0047 & 7.9908 & 3.5846 & 0.6691 \\
\hline
\end{tabular}




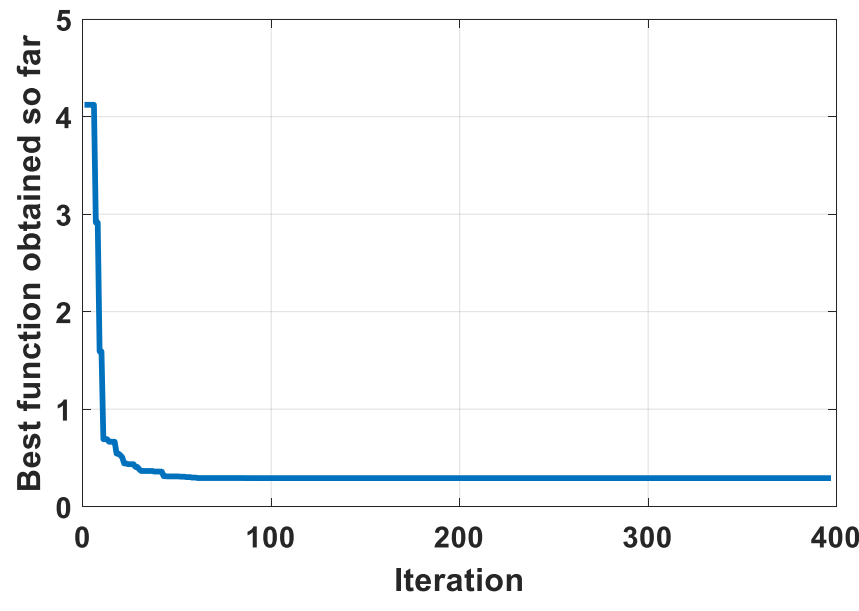

(a) Convergence rate

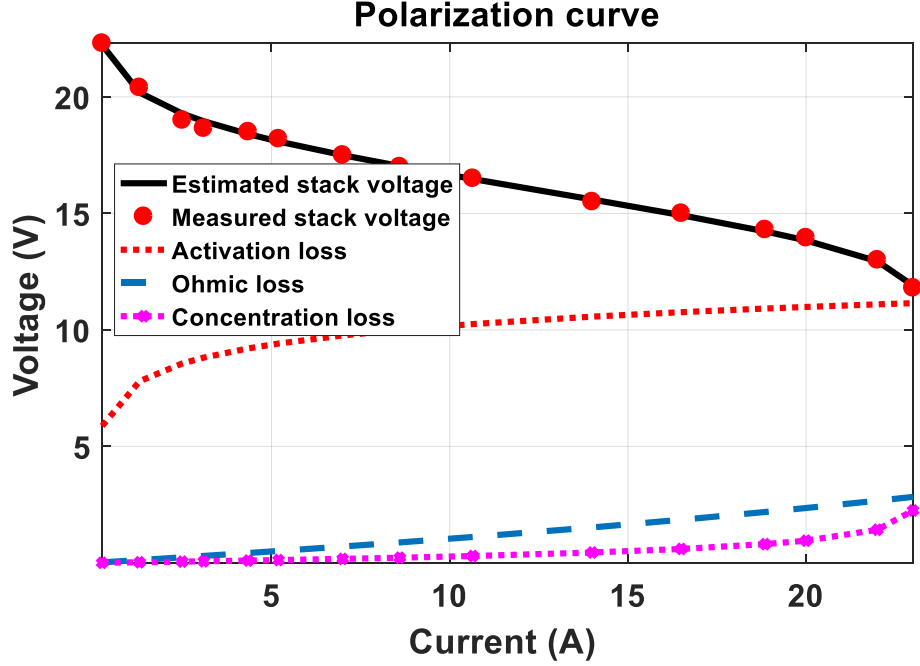

(b) (I-V) polarization curve with different losses

Figure 3. The convergence of COA curve of $250 \mathrm{~W}$ PEM fuel cell and polarization curve at operating conditions \#1.

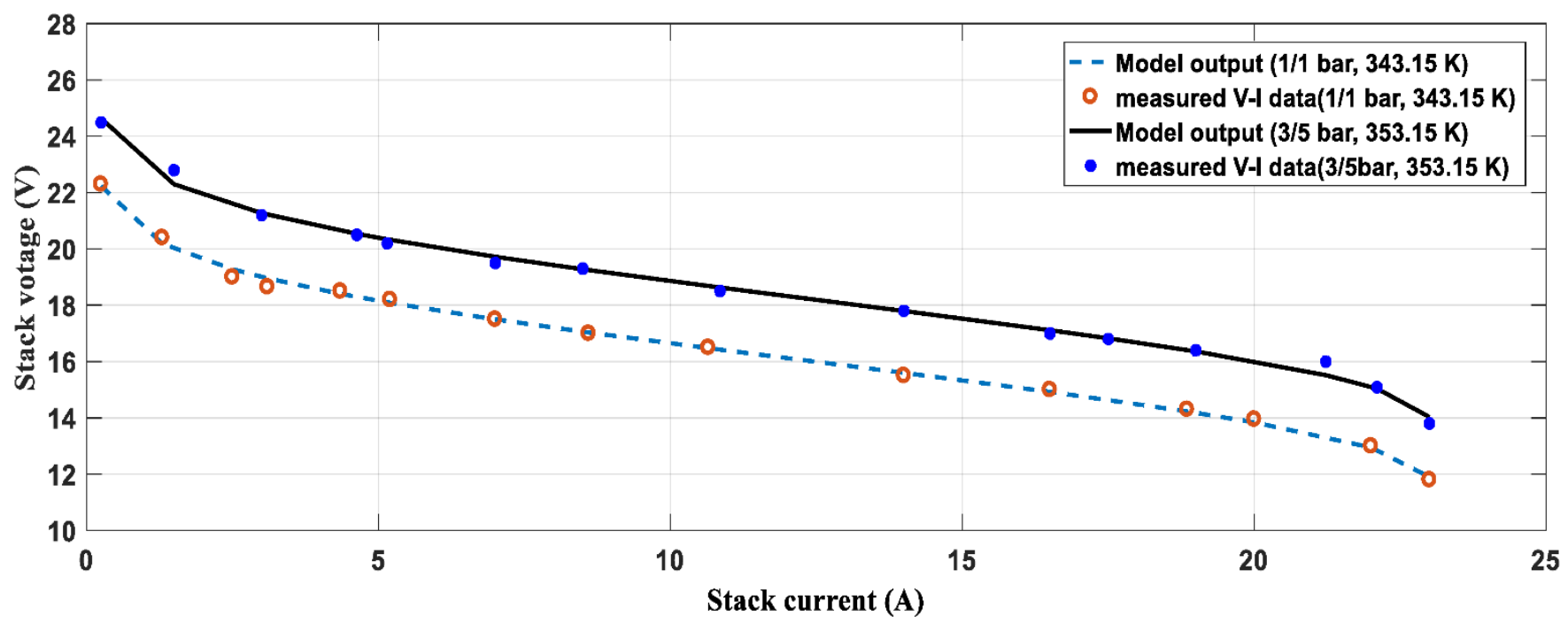

Figure 4. Polarization (V-I) curve of PEM fuel cell at operating conditions \#1 and \# 2.

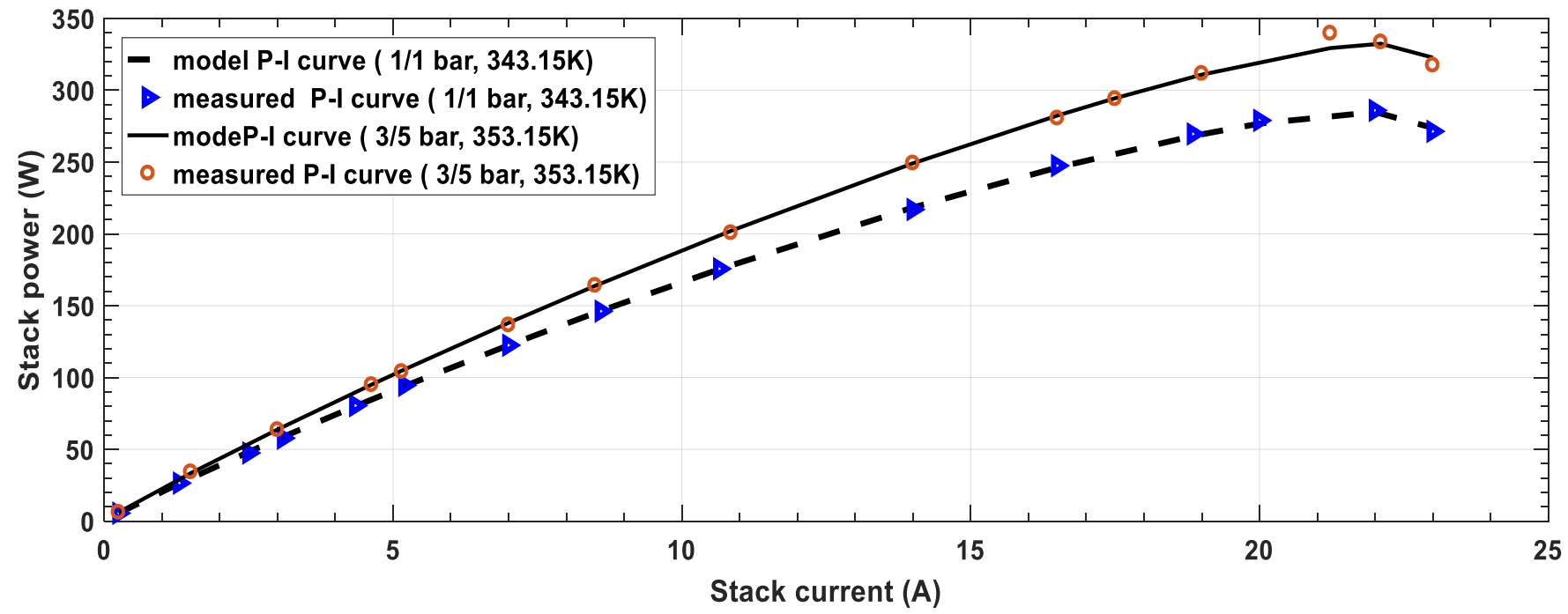

Figure 5. Power (P-I) curve of PEM fuel cell at operating conditions \#1 and \#2. 
At four working settings, two for examining the proposed model and the other ones for legalizing the model, a set of the polarization curves is built. Figure 6 clarifies the polarization curves (V-I curves) at ( $3 / 5$ bar and $353.15 \mathrm{k} / 2.5 / 3$ bar and $343.15 \mathrm{k} / 1.5 / 1.5 \mathrm{bar}$ and $343.15 \mathrm{k} / 1 / 1 \mathrm{bar}$ and $343.15 \mathrm{k}$ ). The results obtained show the effectiveness of the proposed algorithm in estimating an accurate model for the PEM fuel stack.

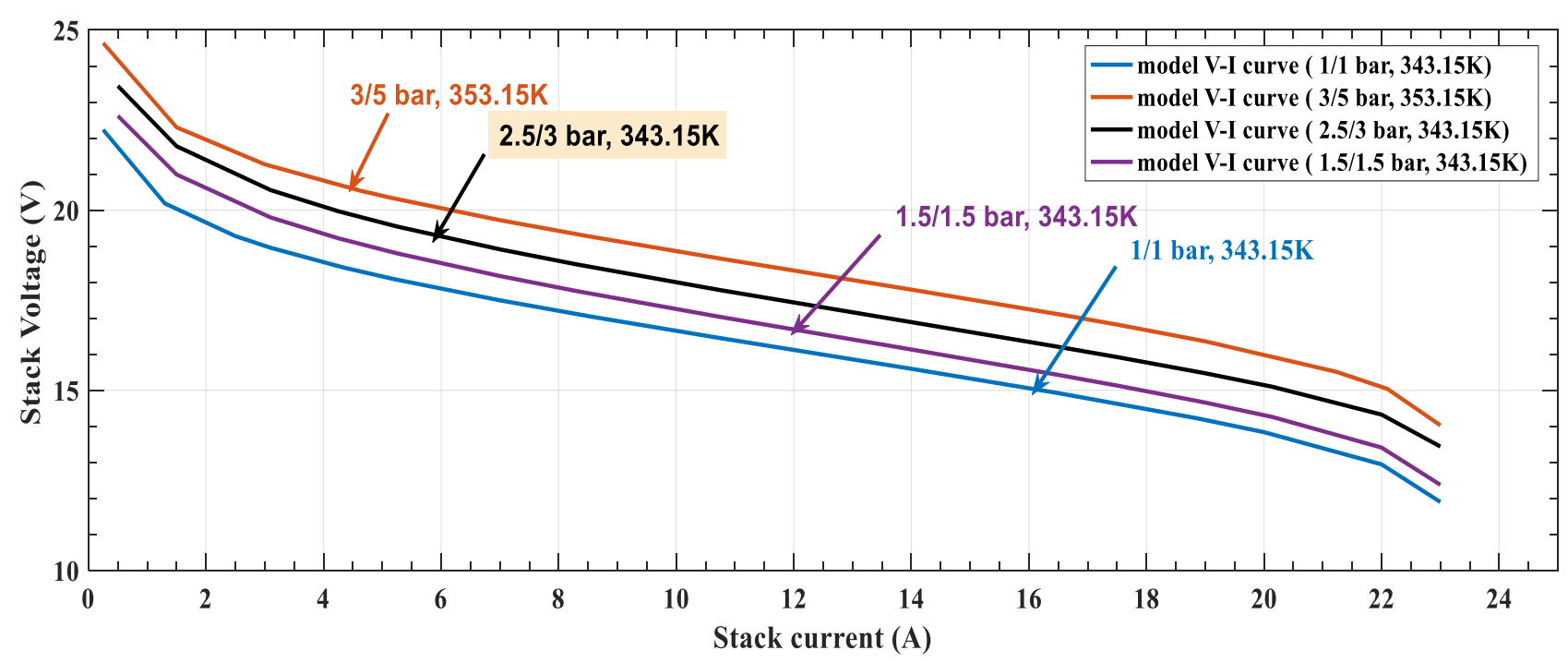

Figure 6. A set of polarization (V-I) curves of PEM fuel cells at four operating conditions.

\subsection{Case 2: 6000 W NedStack PS6 Stack}

In the second case, Nedstack PS6 PEM stack, 65 fuel cells are in series with a rated power of $6 \mathrm{~kW}$. The detailed technical characteristics are explained in Table 1. As procedures carried out for the first case study, the results obtained show that the best value of SSE over the 400 iterations is via the proposed COA. The best fitness is 2.10941 which is lower than the corresponding SSE obtained by the selected competitive methods SSA, SCA, MFO, and PSO. Moreover, the results, also, have been compared to the recent literature IAEO [44] and CFSO [45]. The results presented in Table 5 emphasize that COA outperforms all reported methods. The optimal parameters of the generated model using the optimization methods are presented in Table 5 . The generating model used the estimated parameters have been used to construct the polarization (I-V) curve, as shown in Figure 7. Moreover, the effect of various losses is shown in Figure $7 \mathrm{~b}$. The high closeness between generated model and the data-set (I-V) confirms the accuracy of the proposed COA. Again, the convergence rate of COA is compared to others, confirming the effectiveness of the proposed COA to generate a more precise model of PEM fuel cells stack.

Table 5. The optimal parameters of the generated model using the optimization methods.

\begin{tabular}{cccccccc}
\hline $\begin{array}{c}\text { PEMFC } \\
\text { Parameter }\end{array}$ & $\begin{array}{c}\text { IAEO } \\
{[44]}\end{array}$ & CFSO [45] & $\begin{array}{c}\text { SSA } \\
{[46]}\end{array}$ & $\begin{array}{c}\text { SCA } \\
{[47]}\end{array}$ & MFO [48] & $\begin{array}{c}\text { PSO } \\
\text { [16] }\end{array}$ & $\begin{array}{c}\text { Proposed } \\
\text { COA }\end{array}$ \\
\hline$\xi_{1}$ & -0.981 & -0.9822 & -1.0996 & -1.1997 & -1.1730 & -1.1997 \\
$\xi_{2}$ & $3.383 \times 10^{-3}$ & $3.595 \times 10^{-3}$ & $3.92 \times 10^{-3}$ & $3.48 \times 10^{-3}$ & $3.98 \times 10^{-3}$ & $4.37 \times 10^{-3}$ & -1.1997 \\
$\xi_{3}$ & $7.759 \times 10^{-5}$ & $9.481 \times 10^{-5}$ & $8.75 \times 10^{-5}$ & $3.60 \times 10^{-5}$ & $7.67 \times 10^{-5}$ & $9.86 \times 10^{-5}$ & $3.60 \times 10^{-5}$ \\
$\xi_{4}$ & $-9.54 \times 10^{-5}$ & $-9.54 \times 10^{-5}$ & $-9.54 \times 10^{-5}$ & $-9.54 \times 10^{-5}$ & $-9.54 \times 10^{-5}$ & $-9.54 \times 10^{-5}$ & $-9.54 \times 10^{-5}$ \\
$\lambda$ & 13 & 13.465 & 23 & 23 & 23 & 21.216 & 21.211 \\
$\mathrm{R}_{\mathrm{C}}$ & $1.00 \times 10^{-4}$ & $1.00 \times 10^{-4}$ & $1.00 \times 10^{-4}$ & $1.34 \times 10^{-4}$ & $1.18 \times 10^{-4}$ & $1.00 \times 10^{-4}$ & $1.00 \times 10^{-4}$ \\
$b$ & 0.047 & 0.0136 & 0.0302 & 0.0238 & 0.0248 & 0.0136 & 0.0136 \\
SSE & 2.176 & 2.1459 & 2.30110 & 2.30928 & 2.18375 & 2.10983 & 2.10941 \\
\hline
\end{tabular}




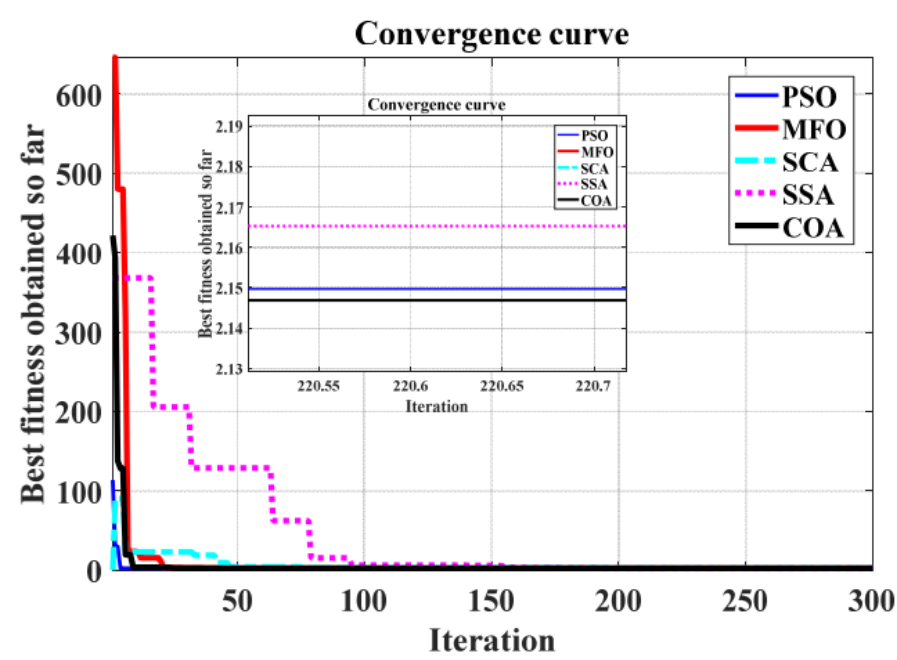

(a) Convergence rate

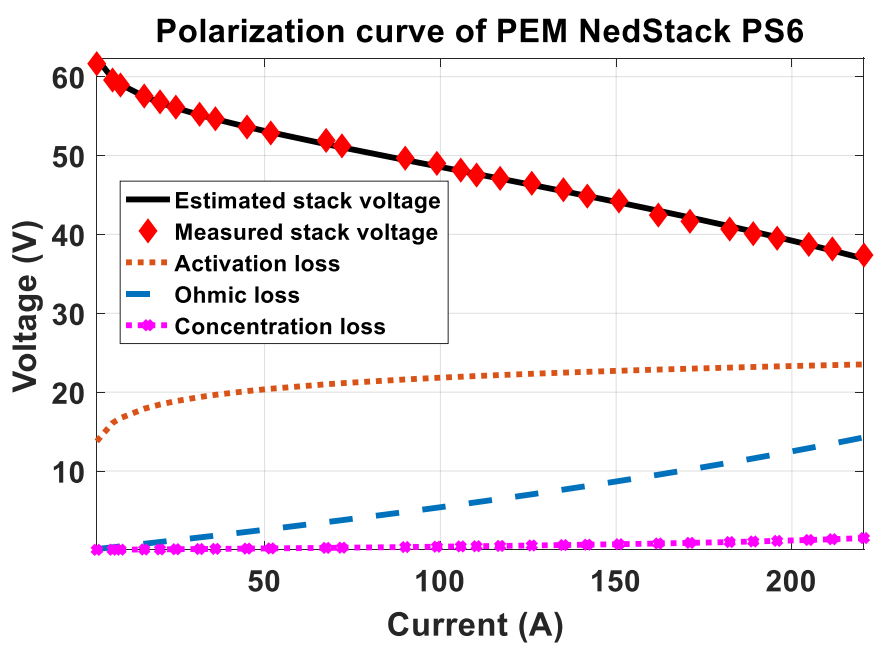

(b) (I-V) polarization curve with different losses

Figure 7. The convergence of COA curve of $6 \mathrm{~kW}$ NedStack PS6 PEM fuel cell and polarization curve.

\section{Conclusions}

In this paper, a bio-inspired COA has been introduced for estimating an accurate model of PEM fuel cells. The algorithm identifies the optimum values of the model parameters accurately. Two practical cases including $250 \mathrm{~W}$ and $6 \mathrm{~kW}$ NedStack PS6 PEM system have been used to analyze the performance of the proposed COA method and its ability to generate a reliable model of PEM fuel cells stack. In COA the optimization process is based on the social structure and exchanging experiences among the coyotes. COA has only two parameters, the number of packs and the number of coyotes per pack that defines the population size, $N_{P}$ and $N_{c}$. No control parameters are required for COA. The features of COA are; rapidly, smoothly, and steadily convergence; no required efforts are needed to adjust the control variable of the algorithm as compared to other algorithms. The simulation results including the extracting parameters of the PEM stack and the minimum deviation between the generated model and the measured data point (I-V) are compared to the well-known optimizers. According to the numerical results obtained, COA has the ability and stability to estimate the global optimal parameters of the PEM fuel cell stack with minimal SEE compared to other algorithms. Well agreements between the estimated model using COA and the measured data ensure the effectiveness of COA and the accuracy of the PEM fuel cell stack model. The low value of the SSE emphasizes that COA is an effective and reliable technique in modeling PEM fuel. Thus, the COA is suggested to solve more complicated and large engineering optimization problems.

Author Contributions: All authors have contributed to the preparation of this manuscript. A.A. and R.A.E.-S. designed the idea strategy, studied the data, and wrote the original manuscript. M.M.F.D. and K.M. revised and proofread the manuscript, and designed some figures. Finally, R.A.E.-S. and M.L. reviewing, editing, and supporting different improvements for the manuscript. All authors have read and agreed to the published version of the manuscript.

Funding: This work was supported by the Department of Electrical Engineering and Automation, Aalto University, Espoo, Finland.

Institutional Review Board Statement: Not applicable.

Informed Consent Statement: Not applicable.

Data Availability Statement: The data presented in this study are available on request from the corresponding author.

Conflicts of Interest: The authors declare no conflict of interest. 


\section{References}

1. Nikiforow, K.; Pennanen, J.; Ihonen, J.; Uski, S.; Koski, P. Power ramp rate capabilities of a $5 \mathrm{~kW}$ proton exchange membrane fuel cell system with discrete ejector control. J. Power Sources 2018, 381, 30-37. [CrossRef]

2. Ahmed, K.; Farrok, O.; Rahman, M.M.; Ali, M.S.; Haque, M.M.; Azad, A.K. Proton Exchange Membrane Hydrogen Fuel Cell as the Grid Connected Power Generator. Energies 2020, 13, 6679. [CrossRef]

3. Qiu, Y.; Wu, P.; Miao, T.; Liang, J.; Jiao, K.; Li, T.; Lin, J.; Zhang, J. An Intelligent Approach for Contact Pressure Optimization of PEM Fuel Cell Gas Diffusion Layers. Appl. Sci. 2020, 10, 4194. [CrossRef]

4. Derbeli, M.; Barambones, O.; Sbita, L. A Robust Maximum Power Point Tracking Control Method for a PEM Fuel Cell Power System. Appl. Sci. 2018, 8, 2449. [CrossRef]

5. Ansari, S.A.; Khalid, M.; Kamal, K.; Abdul Hussain Ratlamwala, T.; Hussain, G.; Alkahtani, M. Modeling and Simulation of a Proton Exchange Membrane Fuel Cell Alongside a Waste Heat Recovery System Based on the Organic Rankine Cycle in MATLAB/SIMULINK Environment. Sustainability 2021, 13, 1218. [CrossRef]

6. Veziroğlu, T.N. Foreword. In PEM Fuel Cells; Elsevier: Amsterdam, The Netherlands, 2013; pp. ix-x.

7. Ihonen, J. Value Chain Analysis of Hydrogen in Finland. 2013. Available online: http://www.topnest.no/attachments/article/12 /WP3_H2FC\%20Finland_revised.pdf (accessed on 25 February 2021).

8. Ihonen, J.; Koski, P.; Pulkkinen, V.; Keränen, T.; Karimäki, H.; Auvinen, S.; Nikiforow, K.; Kotisaari, M.; Tuiskula, H.; Viitakangas, J. Operational experiences of PEMFC pilot plant using low grade hydrogen from sodium chlorate production process. Int. J. Hydrog. Energy 2017, 42, 27269-27283. [CrossRef]

9. Yan, C.; Chen, J.; Liu, H.; Lu, H. Model-Based Fault Tolerant Control for the Thermal Management of PEMFC Systems. IEEE Trans. Ind. Electron. 2020, 67, 2875-2884. [CrossRef]

10. Abbas, A.S.; El-Sehiemy, R.A.; Abou El-Ela, A.; Ali, E.S.; Mahmoud, K.; Lehtonen, M.; Darwish, M.M.F. Optimal Harmonic Mitigation in Distribution Systems with Inverter Based Distributed Generation. Appl. Sci. 2021, 11, 774. [CrossRef]

11. Abdel-Nasser, M.; Mahmoud, K.; Lehtonen, M. Reliable Solar Irradiance Forecasting Approach Based on Choquet Integral and Deep LSTMs. IEEE Trans. Ind. Inform. 2021, 17, 1873-1881. [CrossRef]

12. Bayoumi, A.S.; El-Sehiemy, R.A.; Mahmoud, K.; Lehtonen, M.; Darwish, M.M.F. Assessment of an Improved Three-Diode against Modified Two-Diode Patterns of MCS Solar Cells Associated with Soft Parameter Estimation Paradigms. Appl. Sci. 2021, 11, 1055. [CrossRef]

13. Yuan, X.; Liu, Y.; Bucknall, R. A Novel Design of a Solid Oxide Fuel Cell-Based Combined Cooling, Heat and Power Residential System in the U.K. IEEE Trans. Ind. Appl. 2021, 57, 805-813. [CrossRef]

14. Abouelatta, M.A.; Ward, S.A.; Sayed, A.M.; Mahmoud, K.; Lehtonen, M.; Darwish, M.M.F. Fast Corona Discharge Assessment Using FDM integrated with Full Multigrid Method in HVDC Transmission Lines Considering Wind Impact. IEEE Access 2020, 8 , 225872-225883. [CrossRef]

15. Chavan, S.L.; Talange, D.B. Electrical equivalent circuit modeling and parameter estimation for PEM fuel cell. In Proceedings of the 2017 Innovations in Power and Advanced Computing Technologies, i-PACT 2017, Vellore, India, 21-22 April 2017; Institute of Electrical and Electronics Engineers Inc.: Piscataway, NJ, USA, 2017; Volume 2017, pp. 1-6.

16. Sedighizadeh, M.; Rezazadeh, A.; Khoddam, M.; Zarean, N. Parameter Optimization for a Pemfc Model With Particle Swarm Optimization. Int. J. Eng. Appl. Sci. 2011, 3, 102-108.

17. Forrai, A.; Funato, H.; Yanagita, Y.; Kato, Y. Fuel-cell parameter estimation and diagnostics. IEEE Trans. Energy Convers. 2005, 20, 668-675. [CrossRef]

18. Mo, Z.-J.; Zhu, X.-J.; Wei, L.-Y.; Cao, G.-Y. Parameter optimization for a PEMFC model with a hybrid genetic algorithm. Int. J. Energy Res. 2006, 30, 585-597. [CrossRef]

19. Outeiro, M.T.; Chibante, R.; Carvalho, A.S.; de Almeida, A.T. A new parameter extraction method for accurate modeling of PEM fuel cells. Int. J. Energy Res. 2009, 33, 978-988. [CrossRef]

20. Ali, M.N.; Mahmoud, K.; Lehtonen, M.; Darwish, M.M.F. An Efficient Fuzzy-Logic Based Variable-Step Incremental Conductance MPPT Method for Grid-connected PV Systems. IEEE Access 2021, 9, 26420-26430. [CrossRef]

21. Mansour, D.-E.A.; Abdel-Gawad, N.M.K.; El Dein, A.Z.; Ahmed, H.M.; Darwish, M.M.F.; Lehtonen, M. Recent Advances in Polymer Nanocomposites Based on Polyethylene and Polyvinylchloride for Power Cables. Materials 2020, 14, 66. [CrossRef] [PubMed]

22. Elsisi, M.; Tran, M.-Q.; Mahmoud, K.; Lehtonen, M.; Darwish, M.M.F. Deep Learning-Based Industry 4.0 and Internet of Things towards Effective Energy Management for Smart Buildings. Sensors 2021, 21, 1038. [CrossRef]

23. Ali, M.N.; Mahmoud, K.; Lehtonen, M.; Darwish, M.M.F. Promising MPPT Methods Combining Metaheuristic, Fuzzy-Logic and ANN Techniques for Grid-Connected Photovoltaic. Sensors 2021, 21, 1244. [CrossRef] [PubMed]

24. Ghoneim, S.M.; Mahmoud, K.; Lehtonen, M.; Darwish, M.M.F. Enhancing Diagnostic Accuracy of Transformer Faults Using Teaching-Learning Based Optimization. IEEE Access 2021, 9. [CrossRef]

25. Sun, Z.; Wang, N.; Bi, Y.; Srinivasan, D. Parameter identification of PEMFC model based on hybrid adaptive differential evolution algorithm. Energy 2015, 90, 1334-1341. [CrossRef]

26. El-Fergany, A.A. Electrical characterisation of proton exchange membrane fuel cells stack using grasshopper optimizer. IET Renew. Power Gener. 2018, 12, 9-17. [CrossRef] 
27. Fathy, A.; Rezk, H. Multi-verse optimizer for identifying the optimal parameters of PEMFC model. Energy 2018, 143, 634-644. [CrossRef]

28. Zhang, W.; Wang, N.; Yang, S. Hybrid artificial bee colony algorithm for parameter estimation of proton exchange membrane fuel cell. Int. J. Hydrog. Energy 2013, 38, 5796-5806. [CrossRef]

29. Askarzadeh, A.; Coelho, L.D.S. A backtracking search algorithm combined with Burger's chaotic map for parameter estimation of PEMFC electrochemical model. Int. J. Hydrog. Energy 2014, 39, 11165-11174. [CrossRef]

30. Yang, S.; Wang, N. A novel P systems based optimization algorithm for parameter estimation of proton exchange membrane fuel cell model. Int. J. Hydrog. Energy 2012, 37, 8465-8476. [CrossRef]

31. Niu, Q.; Zhang, L.; Li, K. A biogeography-based optimization algorithm with mutation strategies for model parameter estimation of solar and fuel cells. Energy Convers. Manag. 2014, 86, 1173-1185. [CrossRef]

32. Askarzadeh, A. Parameter estimation of fuel cell polarization curve using BMO algorithm. Int. J. Hydrog. Energy 2013, 38, 15405-15413. [CrossRef]

33. Ohenoja, M.; Leiviskä, K. Validation of genetic algorithm results in a fuel cell model. Int. J. Hydrog. Energy 2010, 35, 12618-12625. [CrossRef]

34. Priya, K.; Sudhakar Babu, T.; Balasubramanian, K.; Sathish Kumar, K.; Rajasekar, N. A novel approach for fuel cell parameter estimation using simple Genetic Algorithm. Sustain. Energy Technol. Assess 2015, 12, 46-52. [CrossRef]

35. Askarzadeh, A.; Rezazadeh, A. An innovative global harmony search algorithm for parameter identification of a PEM fuel cell model. IEEE Trans. Ind. Electron. 2012, 59, 3473-3480. [CrossRef]

36. Elsisi, M.; Mahmoud, K.; Lehtonen, M.; Darwish, M.M.F. An Improved Neural Network Algorithm to Efficiently Track Various Trajectories of Robot Manipulator Arms. IEEE Access 2021, 9, 11911-11920. [CrossRef]

37. Elsisi, M.; Mahmoud, K.; Lehtonen, M.; Darwish, M.M.F. Reliable Industry 4.0 Based on Machine Learning and IoT for Analyzing, Monitoring, and Securing Smart Meters. Sensors 2021, 21, 487. [CrossRef] [PubMed]

38. Yuan, Z.; Wang, W.; Wang, H.; Ashourian, M. Parameter identification of PEMFC based on Convolutional neural network optimized by balanced deer hunting optimization algorithm. Energy Rep. 2020, 6, 1572-1580. [CrossRef]

39. Santarelli, M.G.; Torchio, M.F.; Cochis, P. Parameters estimation of a PEM fuel cell polarization curve and analysis of their behavior with temperature. J. Power Sources 2006. [CrossRef]

40. Sun, Z.; Cao, D.; Ling, Y.; Xiang, F.; Sun, Z.; Wu, F. Proton exchange membrane fuel cell model parameter identification based on dynamic differential evolution with collective guidance factor algorithm. Energy 2021. [CrossRef]

41. Mann, R.F.; Amphlett, J.C.; Hooper, M.A.I.; Jensen, H.M.; Peppley, B.A.; Roberge, P.R. Development and application of a generalized steady-state electrochemical model for a PEM fuel cell. J. Power Sources 2000, 86, 173-180. [CrossRef]

42. Pierezan, J.; Dos Santos Coelho, L. Coyote Optimization Algorithm: A New Metaheuristic for Global Optimization Problems. In Proceedings of the 2018 IEEE Congress on Evolutionary Computation, CEC 2018 Proceedings, Rio de Janeiro, Brazil, 8-13 July 2018; Institute of Electrical and Electronics Engineers Inc.: Piscataway, NJ, USA, 2018.

43. Fawzi, M.; El-Fergany, A.A.; Hasanien, H.M. Effective methodology based on neural network optimizer for extracting model parameters of PEM fuel cells. Int. J. Energy Res. 2019, 43, 8136-8147. [CrossRef]

44. Rizk-Allah, R.M.; El-Fergany, A.A. Artificial ecosystem optimizer for parameters identification of proton exchange membrane fuel cells model. Int. J. Hydrog. Energy 2020. [CrossRef]

45. Cao, Y.; Kou, X.; Wu, Y.; Jermsittiparsert, K.; Yildizbasi, A. PEM fuel cells model parameter identification based on a new improved fluid search optimization algorithm. Energy Rep. 2020, 6, 813-823. [CrossRef]

46. El-Fergany, A.A. Extracting optimal parameters of PEM fuel cells using Salp Swarm Optimizer. Renew. Energy 2018, 119, 641-648. [CrossRef]

47. Mirjalili, S. SCA: A Sine Cosine Algorithm for solving optimization problems. Knowl. Based Syst. 2016, 96, 120-133. [CrossRef]

48. Ben Messaoud, R.; Midouni, A.; Hajji, S. PEM fuel cell model parameters extraction based on moth-flame optimization. Chem. Eng. Sci. 2021, 229, 116100. [CrossRef] 